\title{
6: 24883143-24894257
}

National Cancer Institute

\section{Source}

National Cancer Institute. 6: 24883143-24894257. NCI Thesaurus. Code C42388.

Physical location of GMNN_Gene 